$1-1-1967$

\title{
Specific gravity and fiber length of some hybrid poplars growing in West Virginia
}

\author{
J.R. Hamilton \\ G. W. Wendel
}

Follow this and additional works at: https://researchrepository.wvu.edu/ wv_agricultural_and_forestry_experiment_station_bulletins

\section{Digital Commons Citation}

Hamilton, J. R. and Wendel, G. W., "Specific gravity and fiber length of some hybrid poplars growing in West Virginia" (1967). West Virginia Agricultural and Forestry Experiment Station Bulletins. 556T.

https://researchrepository.wvu.edu/wv_agricultural_and_forestry_experiment_station_bulletins/673 @ WVU. It has been accepted for inclusion in West Virginia Agricultural and Forestry Experiment Station Bulletins by an authorized administrator of The Research Repository @ WVU. For more information, please contact ian.harmon@mail.wvu.edu. 
West Virginia University Libraries

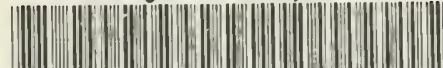

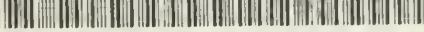

308021004938289 



\section{Specific Gravity and Fiber Length Of Some Hybrid Poplars Growing in West Virginia}

WEST VIRGINIA UNIVERSITY

AGRICULTURAL EXPERIMENT STATION

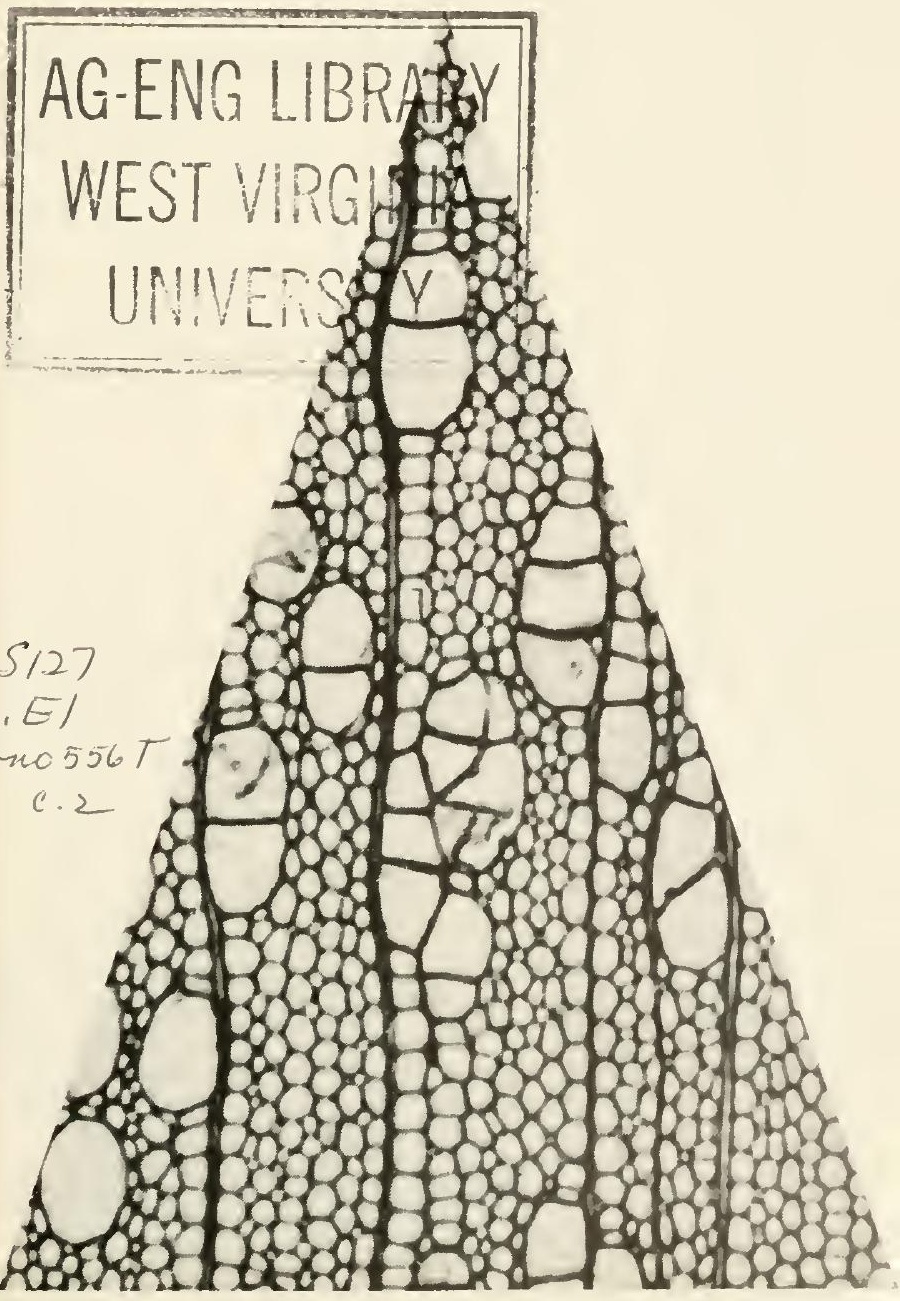




\section{THE AUTHORS}

J. R. Hamilton is Wood Scientist, West Virginia University Agricultural Experiment Station. G. W. Wendel is Associate Silviculturist, Timber and Watershed Laboratory, Northeastern Forest Experiment Station, U. S. Forest Service.

West Virginia University Agrigultural Experinent Station College of Agriculture and Forestry

A. H. VanLandingham MORGANTOWN 


\section{Specific Gravity and Fiber Length of Some Hybrid Poplars Growing in West Virginia}

\section{J. R. HAMILTON AND G. W. WENDEL}

THE wood of the poplars and their hybrids is widely used in Europe for veneers, building lumber, box lumber, and pulpwood (7). In the

United States the aspens, Populus tremuloides Michx. and P. grandidentata Michx., are important as pulpwood species and to a lesser extent for corestock, match wood, crating, and excelsior (2). The cottonwoods, particularly $P$. deltoides Bartr., are sought after for factory and box lumber, package and commercial veneer, and pulpwood (6).

In 1951, 50 hybrid poplar clones developed by the Northeastern Forest Experiment Station were outplanted in West Virginia as part of a region-wide test. Thirteen of these clones (Table 1), all of which have one parent from the section Tacamahaca, have been outstanding in their survival and growth. Eschner (3) reported the growth of these clones in 1960 but there is little published information concerning their woor properties. As a result, a cooperative studly was undertaken by the Northeastern Forest Experiment Station and West Virginia University to determine the fiber length and specific gravity of these clones.

\section{TABLE I}

\section{Clone Numbers and Parentage ${ }^{1}$ of the Best Performing Clones at Horseshoe Run}

Clone Number

NE-29

$\mathrm{NE}-41,42$

$\mathrm{NE}-13,46,47,49,50$

$\mathrm{NE}-51,52$

NE-53

NE-206

NE-256

\section{Parentage}

Populus nigra cv. Charkowiensis x P.

trichocarpa

P. maximowiczii x P. trichocarpa

P. maximowiczii x cv. Berolinensis

P. maximowiczii x P. nigra cv. Plantierensis

$P$. maximowiczii $\mathrm{x}$ P. nigra cv. Caudina

P. deltoides $\times$ P. trichocarpa

$P$. deltoides (v. Angulata $\times$ P. trichocarpa

T. Full names are in accordance with the International Code of Nomenclature for Cultivated Plants. Report of the standing Executive Committee on the application to the genus Populus. U.N. FAO. International poplar Comm., sth Session (Madrid) . 13 pp. 1955. (Mimco.) 


\section{MATERIALS AND METHODS}

The outplanting of particular interest was established in 1951 on Horseshoe Run near Parsons, West Virginia. The soil in this area is a Pope gravelly silt loam, alluvial in origin, well drained, derived from acid standstone and shales, with a $\mathrm{pH}$ of 5.5. The planting was replicated twice. Cuttings were planted at a $4 \mathrm{x}$ 4-foot spacing and cultivated during the first two growing seasons. Two thinnings, one in 1960 and one in 1965, have reduced the original 16 trees in each of the 13 best clonal plots to four.

Two trees were ranclomly selected from each replicate of the 13 outstanding clones for determination of fiber length and specific gravity. Four $11 \mathrm{~mm}$ diameter increment cores, containing the outermost five annual increments were taken from points corresponding to the cardinal directions, at 4.5 feet above ground level on each tree. The cores were sealed immediately in numbered plastic bags and frozen to prescrve them in the fresh condition. At this time, measurements were also made of the total height and cliameter at breast height (d.b.h.) of each of the four trees in the clonal plots.

Initial preparation in the laboratory consisted of removing the last formed increment, so as to avoid compressed rood, and excising the next four increments from the remainder of the core. In this way relatively undisturbed increments from 1961 through 1964 were obtained for specific analysis.

Sixteen determinations of specific gravity were made for each clone, four from each of two trees in each of two replications, using the maximum moisture content method detailed by Smith (8). Saturation was insured by intermittent evacuation under water for a period of seven days. For fiber measurements, the entire cores were cut into thin chips and macerated in equal parts of 30 per cent hydrogen peroxide and glacial acetic acid. Lengths were measured to the nearest $0.01 \mathrm{~mm}$ using a projection microscope and calibrated rule. Fifty fiber length determinations were made from each core, using care to consider only whole fibers.

The data were analyzed by analysis of variance using the average specific gravity and fiber length for each clone in each replication. The principal source of variation examined was clone. Significant sources were examined by the Hartley Test of means (9).

\section{RESULTS AND DISCUSSION}

No statistically significant differences in fiber length were detected between the 13 clones examined. The average fiber length of all clones was $1.18 \mathrm{~mm}$ and individual clone arerage ranged between $1.25 \mathrm{~mm}$ and $1.15 \mathrm{~mm}$ (Table 2). 


\section{TABLE 2}

The Tree and Wood Characteristics of 13 Selected Clones of Hybird Poplar at Parsons, West Virginia, Ranked in Order of Hartley Test of Specific Grovity ${ }^{1}$

\begin{tabular}{lcccc}
\hline \hline $\begin{array}{c}\text { Clone } \\
\text { Number }\end{array}$ & $\begin{array}{c}\text { Specific } \\
\text { Gravity }\end{array}$ & $\begin{array}{c}\text { Fiber } \\
\text { Length }\end{array}$ & $\begin{array}{c}\text { Average } \\
\text { D.B.H. }\end{array}$ & $\begin{array}{c}\text { Average } \\
\text { Total Height }\end{array}$ \\
\hline & & mm & inches & feet \\
NE-49 & 0.379 & 1.184 & 4.8 & 52.1 \\
NE-47 & 0.373 & 1.179 & 6.4 & 54.6 \\
NE-42 & 0.342 & 1.213 & 6.9 & 56.1 \\
NE-41 & 0.339 & 1.207 & 7.3 & 58.2 \\
NE-256 & 0.337 & 1.247 & 5.9 & 51.2 \\
NE-50 & 0.335 & 1.195 & 7.9 & 67.2 \\
NE-206 & 0.331 & 1.067 & 5.2 & 51.0 \\
NE-53 & 0.322 & 1.175 & 4.8 & 53.0 \\
NE-51 & 0.318 & 1.177 & 7.1 & 59.0 \\
NE-46 & 0.317 & 1.199 & 8.0 & 66.5 \\
NE-52 & 0.312 & 1.173 & 6.3 & 52.2 \\
NE-29 & 0.301 & 1.149 & 5.5 & 49.9 \\
NE-43 & 0.293 & 1.205 & 7.8 & 63.1 \\
& & & & \\
\hline
\end{tabular}

1 Clones within a group do not differ from one another at the 0.05 probability level.

The specific gravity of the samples differed significantly between clones. The average specific gravity for individual clones ranged between 0.38 and 0.29 and the average for all clones was 0.33 (Table 2). A ranking of clones by specific gravity indicated four distinct groups, which differed significantly from one another but did not differ within a group. Clones 47 and 49 contained wood which was distinctly heavier than the others. These clones had an average specific gravity of 0.38 . Clone 47 is commonly known as the "Oxford" poplar and has been highly recommended in many countries of Europe. At the other extreme, clones 29 and 43 averaged only 0.30 . The specific gravity of the remaining nine clones fell between these two extremes and was close to the overall average.

These specific gravity values are similar to published values for other Populus species. Native P. tremuloides, P. trichocarpa, and P. regen- 
eraia are reported to have average specific gravities of $0.35,0.36$, and 0.38 respectively $(1,5,10)$. In addition, the specific gravity of $P$. deltoides has been observed to range between 0.32 and 0.46 on two sites in Mississippi (4) and 0.33 and 0.40 in east-central Illinois (11).

\section{SUMMARY AND CONCLUSIONS}

An examination of two of the wood properties and growth of hybrid poplar indicaied that decisions concerning the choice of specific clones for planting might profitably include information concerning wood characteristics in addition to that of survival and growth.

Among the 13 clones studied there was a difference of 0.09 in specific gravity. The heaviest was 24 per cent greater than the lightest. No significant differences in fiber length were observed between clones.

\section{LITERATURE CITED}

1. Anonymous, 1955. Wood llandbook. U.S. Dept. of Agr., For. Ser., Agr. Handbook No. 72. 528 pp., illus.

2. Betts, H. S. 1945. Ispen. U.S. Dept. of Agr., For. Ser., American Woods Series.

3. Eschner, A. R. 1960. Observations on a Hybid Poplar Test Planting in West Virginia. U.S. For. Seï., Northeast For. Exp. Sta. Res. Note 111. 4 pp., illus.

4. Farmer, R. E. and J. R. Wilcox. 1966. Specific Gravity Variation in a Lower Mississippi Valley Cottonwood Population. TAPPI 49 (5): 210-211.

5. Kennedy, R. W. and J. H. G. Smith. 1959. The Effects of Some Genetic and Environmental Factors on Wood Quality in Poplar. Pulp Paper Mag. Canada. 60: $1-2$.

6. Putnam, J. A., Fumival, G. H. and J. S. Mcknight, 1960. Management and Inventory of Southern Hardwoods. L.S. Dept. of Agr., Agr. Handbook No. 181. 102 pp., illus.

7. Schreiner, 1. J. 1959. Production of Poplar in Europe and Its Significance and Application in the United States. U.S. Dept. of Agr., For. Ser., Agr. Handbook No. 150. 124 pp., illus.

8. Smith, D. M. 1954, Maximum Moisture Content Method for Determining Specific Gravity of Small Wood Samples. U. S. Dept. of Agr., For. Ser., For. Prod. Lab. Rept. No. 2014.

9. Snedecor, G. W. 1956. Statistical Methods. Fifth Ed. The Iowa State College Press, Ames, lowa.

10. Van Buijtenen, J. P., D. W. Enspalir and J. R. Pecknan. 1962. Natural Variation in Populus tremuloides Mich., II Variation in Pulp and Papermaking Properties. TAPPI 45:58-61.

11. Walters, C. S. and G. Bruckman. 1965. Variation in Specific Gravity of Cottonwood as Alfected by Tree Sex and Stand Location. Jour. For. 65 (3) : 182-185. 
Digitized by the Internet Archive in 2010 with funding from

Lyrasis Members and Sloan Foundation 


